\title{
Electrocardiogram: the saviour for this patient
}

\author{
A. Chawla $\cdot$ V. Gaikwad $\cdot$ S. Swarup
}

Published online: 8 December 2015

(C) The Author(s) 2015. This article is published with open access at Springerlink.com

A 42-year-old man presented to the emergency department with a history of central non-radiating chest pain lasting for $25 \mathrm{~min}, 2 \mathrm{~h}$ back. The pain was associated with vomiting and sweating, and subsided spontaneously. He was pain free at the time of presentation. He had had similar episode 3 weeks previously, which lasted less than a minute while he was rock climbing. There was history of hyperlipidaemia for which he was not taking any medication. His physical

A. Chawla $(\bowtie) \cdot$ V. Gaikwad

Department of Diagnostic Radiology, Khoo Teck Puat Hospital, 90 Yishun Central,

768828 Yishun, Singapore

e-mail: ashchawla@gmail.com

S. Swarup

Department of Accident and Emergency,

Khoo Teck Puat Hospital,

Yishun, Singapore

Fig. 1 Electrocardiogram on admission examination including cardiac evaluation was within normal limits. The cardiac enzymes were also normal. His electrocardiogram on admission is shown in Fig. 1. What would your diagnosis be and what would you expect to find on cardiac catheterisation?

\section{Answer}

You will find the answer elsewhere in this issue.

Open Access This article is distributed under the terms of the Creative Commons Attribution License which permits any use, distribution, and reproduction in any medium, provided the original author(s) and the source are credited.

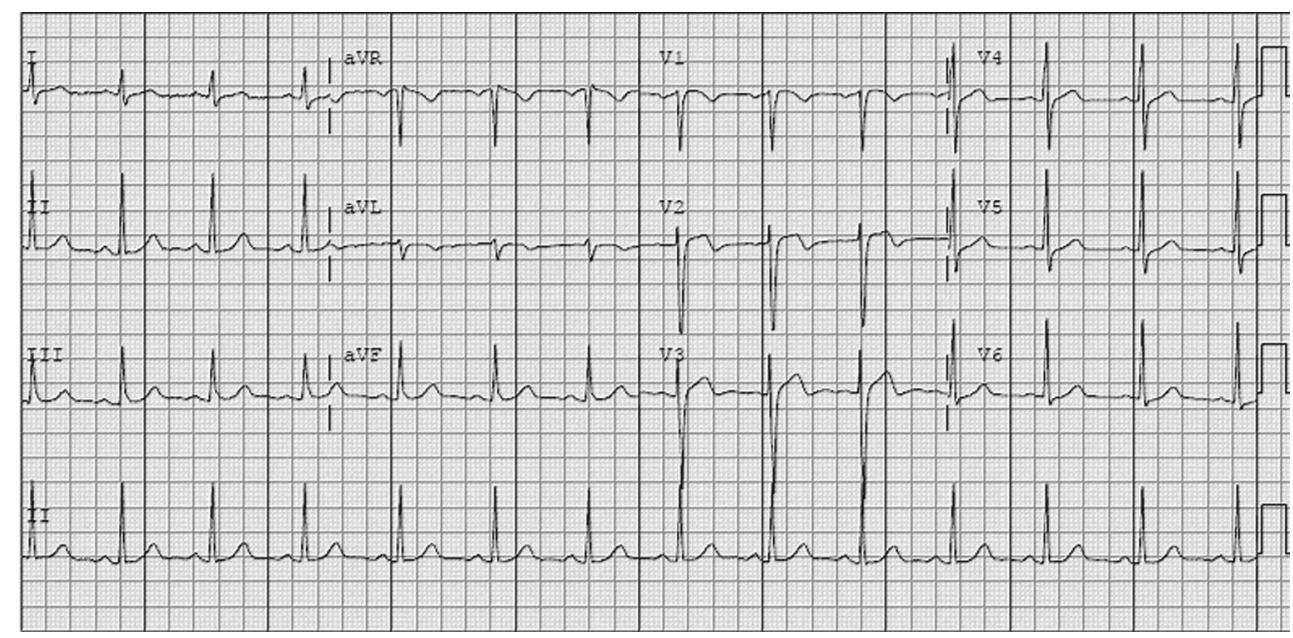

